\title{
Dynamic Relationships between Field Temperatures and Broccoli Head Quality
}

\author{
Robert J. Dufault ${ }^{1}$ \\ Coastal Research and Education Center, Department of Horticulture, Clemson University, 2865 Savannah \\ Highway, Charleston, SC 29414
}

Additional index words. Broccoli oleracea var Italica, heat tolerance, phenology, crucifer, Cruciferae, cole crop, stress

\begin{abstract}
Fifty-six field plantings of 'Baccus', 'Citation', 'Packman', and 'Southern Comet' broccoli were made in Charleston, S.C., at 2-week intervals from February to November from 1990 to 1992 . The objective was to determine broccoli's response to growing season mean (GSM) temperatures for several important market quality characteristics, such as head shape, color, density, leafiness, and bead size. Regression analysis determined whether quality was more affected by GSM minimum ( $\min$ ) or maximum $(\max )$ temperature for each head quality characteristic. Head leafiness and density of 'Baccus' were insensitive to GSM min $\left(7.0\right.$ to $\left.23.5{ }^{\circ} \mathrm{C}\right)$ and GSM max $\left(17.5\right.$ to $\left.32.5^{\circ} \mathrm{C}\right)$ temperatures experienced during these years. 'Baccus' head color was unacceptable at $<20.3^{\circ} \mathrm{C} \mathrm{GSM}$ max and head shape was unacceptable at $<19.8$ and $>26.8{ }^{\circ} \mathrm{C}$ GSM max. 'Citation' head color and leafiness were unacceptable at $>20.5$ and $>20.2{ }^{\circ} \mathrm{C}$ GSM max, respectively. Head density of 'Citation' was unacceptable at $<19.2$ and $>28.9^{\circ} \mathrm{C} \mathrm{GSM}$ max and head shape was unacceptable at $<18.4$ and $>25.7^{\circ} \mathrm{C}$ GSM max. Quality of 'Packman' was unacceptable for head color at $<21.0$ and $>27.3{ }^{\circ} \mathrm{C} \mathrm{GSM}$ max, head leafiness at $>32.0^{\circ} \mathrm{C}$ GSM max, head density at $<8.4$ and $>18.0^{\circ} \mathrm{C}$ GSM min, and head shape at $>22.0{ }^{\circ} \mathrm{C}$ GSM max. 'Southern Comet' head quality was unacceptable for head color at $<9.2$ and $>16.5^{\circ} \mathrm{C} \mathrm{GSM} \mathrm{min,} \mathrm{head} \mathrm{leafiness} \mathrm{at}>32.0^{\circ} \mathrm{C}$ GSM max, head density at $<8.9$ and $>16.2^{\circ} \mathrm{C} \mathrm{GSM} \mathrm{min}$, and head shape at $<21.0$ and $>25.3^{\circ} \mathrm{C}$ GSM max. GSM min or max temperatures did not affect bead size of any cultivar during any planting time studied.
\end{abstract}

Agricultural income has been declining, especially in southeastern states such as South Carolina (Venturella et al., 1988). Producers are searching for new or alternative crops to supplement income from traditional row crops. Broccoli is considered to have commercial potential in South Carolina. From 1970 to 1994, broccoli consumption and land in production has increased from 0.7 to $2.5 \mathrm{~kg} /$ capita and from 16,649 to 43,384 ha, respectively [U.S. Dept. of Agriculture (USDA), 1994]. Although California, Texas, and Mexico are the dominant suppliers of broccoli, areas closer to eastern markets, such as South Carolina, could supply these markets since freight costs would be lower (Venturella et al., 1988). Quality of broccoli is acceptable in South Carolina in spring and fall growing seasons. Yet, to capture a significant portion of the market, long-term production during summer and winter would be desirable.

Broccoli is a cool-season crop and not considered to have heat tolerance. Researchers have investigated the effect of low temperature on flowering in broccoli (Fontes et al., 1967; Fujime, 1988; Gauss and Taylor, 1969; Miller et at., 1985; Wiebe, 1975), but literature describing broccoli's response to high temperature under field conditions is meager. Heather et al. (1992) evaluated 40 hybrid broccoli accessions for heat tolerance in New York and found that heat is more effective in disturbing floret quality when the immature inflorescence measures 5 to $10 \mathrm{~mm}$ in diameter. Although field temperature during their studies was reported, the exact temperature ranges at which quality was disrupted were not defined.

The objective of this study was to determine the field temperature regimes at which quality of four commercial broccoli cultivars became unacceptable for fresh-market

Received for publication 21 Sept. 1995. Accepted for publication 14 Feb. 1996. Technical contribution no. 4157 of the South Carolina Agricultural Experiment Station, Clemson, Univ. The cost of publishing this paper was defrayed in part by the payment of page charges. Under postal regulations, this paper therefore must be hereby marked advertisement solely to indicate this fact.

${ }^{1}$ Professor. use. To accomplish this objective, 56 field plantings were made over a 3-year period in Charleston, S.C., and data were collected on head density, shape, color, leafiness, and bead size and related to temperature.

\section{Materials and Methods}

Fifty-six planting dates were chosen for this study from 1990 to 1992 (Table 1). Late winter, spring, summer, and fall planting dates were selected with the goal of establishing earliest spring, continuous summer, and latest fall production of broccoli in Charleston. There were 18 to 19 planting dates each year and each planting date was separated by about 2 weeks from mid-February

Table 1. Planting dates for broccoli from 1990 to 1992.

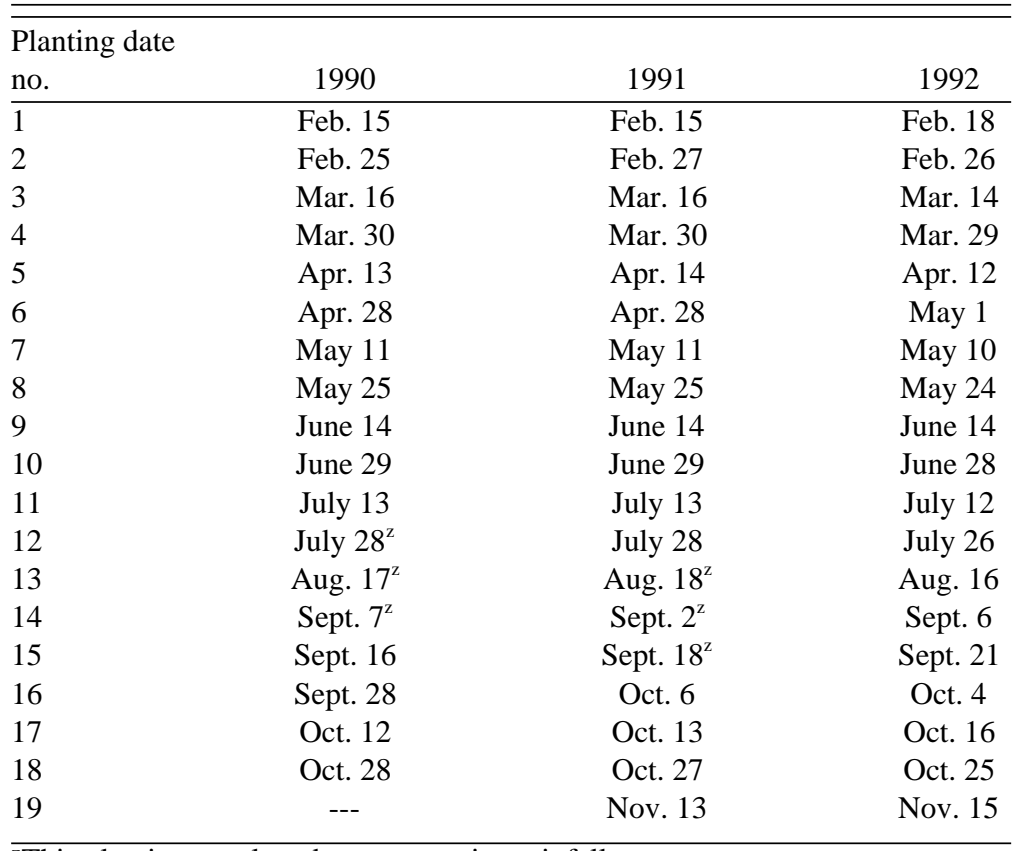

${ }^{\mathrm{z}}$ This planting was lost due to excessive rainfall. 
Table 2. Criteria for determining head quality of broccoli.

\begin{tabular}{|c|c|}
\hline Quality & Criteria \\
\hline \multicolumn{2}{|r|}{ Head density } \\
\hline Acceptable & Generally solid, compact bud clusters with minor or negligible spreading between clusters \\
\hline \multicolumn{2}{|r|}{ Head color } \\
\hline Acceptable & Emerald to olive-green florets \\
\hline Unacceptable & $\begin{array}{l}\text { Lime to yellow to variegated olive green, lime to yellow florets } \\
\qquad \text { Bead size }\end{array}$ \\
\hline Acceptable & Consistently small, medium, or large bead size on individual heads \\
\hline \multicolumn{2}{|r|}{ Head shape } \\
\hline Acceptable & Dome to flat heads \\
\hline Unacceptable & $\begin{array}{r}\text { Concave, hilly, or severely distorted heads } \\
\text { Head leafiness }\end{array}$ \\
\hline Acceptable & Minor and negligible small leaves within individual heads \\
\hline Unacceptable & Moderate to severe head leafiness within individual heads \\
\hline
\end{tabular}

per cultivar were planted in 4.6$\mathrm{m}$-long plots on raised beds in single rows, with seedlings spaced $30 \mathrm{~cm}$ apart within rows and rows spaced $0.9 \mathrm{~m}$ apart. The soil was Yauhannah loamy fine sand (Aquic Hapludults) and all plantings were made in the same field over all years. The experimental design was a latin square with four replications. Commercially accepted pest management (Cook, 1990) and similar cultural practices were used for all planting dates. Before planting, $70 \mathrm{~N}-32 \mathrm{P}-$ $58 \mathrm{~K} \mathrm{~kg} \cdot \mathrm{ha}^{-1}$ was broadcast and disked into the soil. Trifluralin (a.i.) at $0.6 \mathrm{~kg} \cdot \mathrm{ha}^{-1}$ was applied and incorporated into the soil after bed preparation. Nitro-

to mid-November. Four broccoli cultivars-Baccus, Citation, Packman, and Southern Comet-were seeded in the greenhouse and transplanted after a 4-week growth period at the Coastal Research and Education Center in Charleston. Fifteen seedlings gen at $46 \mathrm{~kg} \cdot \mathrm{ha}^{-1}$ was sidedressed about 3 and 5 weeks after transplanting for each planting date treatment.

Individual broccoli central heads were harvested at a $10-\mathrm{cm}$ diameter with $25-\mathrm{cm}$ stem length (measured from the top of the

Table 3. Forward stepwise regression of growing season mean minimum and maximum air temperatures and best equations from polynomial regression that describe head quality of four broccoli cultivars grown in 50 different plantings over a range of time and growing temperatures from 1990 to 1992.

\begin{tabular}{|c|c|c|c|c|}
\hline \multirow[b]{3}{*}{ Cultivar $^{\mathrm{y}}$} & \multirow{2}{*}{\multicolumn{2}{|c|}{$\begin{array}{l}\begin{array}{c}\text { Regression } \\
\text { F value }\end{array} \\
\text { Air temp }\end{array}$}} & \multirow{3}{*}{$\begin{array}{c}R^{2} \text { of } \\
\text { best } \\
\text { equation }\end{array}$} & \multirow{3}{*}{$\begin{array}{c}\text { Best } \\
\text { equation }^{\mathrm{x}}\end{array}$} \\
\hline & & & & \\
\hline & Max & Min & & \\
\hline \multicolumn{5}{|c|}{ Acceptable head color } \\
\hline B & 15.5 & 11.3 & 0.72 & $-80.0+(3.04 \max )-\left(0.038 \max ^{2}\right)+\left(0.00015 \max ^{3}\right)$ \\
\hline $\mathrm{C}$ & 18.7 & 5.5 & 0.55 & $2.27-(0.021 \max )$ \\
\hline $\mathrm{P}$ & 9.1 & 5.1 & 0.65 & $-10.3+(0.298 \max )-\left(0.0020 \max ^{2}\right)$ \\
\hline $\mathrm{SC}$ & 0.7 & 9.2 & 0.71 & $-65.9+(3.33 \mathrm{~min})-\left(0.0545 \mathrm{~min}^{2}\right)+\left(0.00029 \mathrm{~min}^{3}\right)$ \\
\hline \multicolumn{5}{|c|}{ Minimal head leafiness } \\
\hline B & 12.1 & 10.7 & 0.51 & $-0.33+0.033 \max )-\left(0.0002 \max ^{2}\right)$ \\
\hline $\mathrm{C}$ & 104.0 & 1.1 & 0.87 & $3.57-(0.040 \max )$ \\
\hline $\mathrm{P}$ & 12.7 & 8.2 & 0.79 & $29.4-(1.14 \max )+\left(0.0152 \max ^{2}\right)-\left(0.00007 \max ^{3}\right)$ \\
\hline $\mathrm{SC}$ & 11.1 & 3.5 & 0.43 & $1.49-(0.007 \max )$ \\
\hline \multicolumn{5}{|c|}{ Acceptable head density } \\
\hline B & 1.3 & 5.6 & --- & NS \\
\hline $\mathrm{C}$ & 9.5 & 8.9 & 0.75 & $-10.5+(0.306 \max )-\left(0.0020 \max ^{2}\right)$ \\
\hline $\mathrm{P}$ & 2.8 & 9.0 & 0.67 & $-27.8+(1.43 \mathrm{~min})-\left(0.0234 \mathrm{~min}^{2}\right)+\left(0.00013 \mathrm{~min}^{3}\right)$ \\
\hline $\mathrm{SC}$ & 0.8 & 8.2 & 0.61 & $-70.4+(3.61 \mathrm{~min})-\left(0.0600 \mathrm{~min}^{2}\right)+\left(0.00033 \mathrm{~min}^{3}\right)$ \\
\hline \multicolumn{5}{|c|}{ Acceptable head shape } \\
\hline B & 18.8 & 12.5 & 0.78 & $-9.6+(0.285 \max )-\left(0.0019 \max ^{2}\right)$ \\
\hline $\mathrm{C}$ & 7.1 & 3.9 & 0.39 & $-3.6+(0.124 \max )-\left(0.0009 \max ^{2}\right)$ \\
\hline $\mathrm{P}$ & 26.5 & 5.3 & 0.64 & $2.7-(0.026 \max )$ \\
\hline SC & 12.8 & 7.7 & 0.63 & $-11.8+(0.344 \max )-\left(0.0023 \max ^{2}\right)$ \\
\hline \multicolumn{5}{|c|}{ Acceptable bead size } \\
\hline B & 4.2 & 0.1 & --- & NS \\
\hline $\mathrm{C}$ & 3.2 & 3.0 & --- & NS \\
\hline $\mathrm{P}$ & 1.1 & 1.2 & --- & NS \\
\hline $\mathrm{SC}$ & 2.7 & 0.2 & --- & NS \\
\hline
\end{tabular}

${ }^{\mathrm{z}} \mathrm{F}$ values of minimum and maximum air temperatures after forward stepwise regression. Higher $\mathrm{F}$ test indicates a greater effect on quality variables. 'B = 'Baccus', $\mathrm{C}=$ 'Citation', $\mathrm{P}=$ 'Packman', and SC = 'Southern Comet'.

${ }^{\mathrm{x}}$ Best equation from polynomial regression that described culitvar response to temperature. 
head to stem butt). Head shape, color, density, leafiness, and bead size were determined at harvest using USDA standards as guidelines (USDA, 1977) and classified on a percentage basis as commercially acceptable or unacceptable (Table 2). Air temperatures were continuously monitored during the 3 -year period using an thermocouple data logger (model 3020T; ECD, Mulino, Ore.) and multiplexer (series 3000, ECD). Temperatures were recorded hourly during each 24 -h period. For each planting date and cultivar, the minimum (min) and maximum (max) temperatures during each 24-h period were averaged from transplanting to last harvest dates and, in this study, are defined as growing season mean (GSM) temperature. GSM min and max temperatures for each planting date for all 3 years were averaged to derive grand means per planting date for each cultivar.

Forward stepwise regression (FSR) analysis was performed to decide which GSM temperature variable ( $\min$ or max) contributed most to each quality variable using Sigma Stat (Jandel Scientific, San Rafael, Calif.). Normality was determined for the percentage data and the data were arcsin-transformed if not normal and regression was performed on transformed data using Sigma Stat. Of the two GSM temperature variables, the one with the greatest F test was considered to contribute more to the variation of each quality variable. Then, polynomial regression (PR) was performed on the resultant temperature variable derived from FSR to decide the best order model using Sigma Stat. The simplest model with the highest $R^{2}$ was considered to portray the best relationship between GSM temperature and changes in a specific head quality variable. It was important to decide the range of GSM temperatures at which quality was ranked as acceptable. In this study, the acceptable GSM temperature range of performance for each quality variable was defined at the point where $\geq 85 \%$ of the population was classified as acceptable. GSM temperature data versus percent acceptable quality were plotted for each quality variable using Sigma Plot (Jandel Scientific, San Rafael) and, from these graphs, the ranges of acceptable temperatures for quality production were derived.

\section{Results and Discussion}

Of the 56 field plantings, six were lost due to excessive rains and waterlogged soils (Table 1). The 50 remaining plantings were used in regression analysis. FSR analysis denoted the differential varietal response in head quality to GSM min and max temperatures (Table 2). Polynomial regression of head quality variables for each cultivar indicated the order of the best equations that described the effect of the more influential temperature variable (either GSM min or max temperature) from FSR. From the PR equations, distinct GSM temperature ranges for each cultivar were derived to denote when head quality became unacceptable. Shifts from acceptable to unacceptable quality could have occurred at either the lower or higher GSM temperature extremes, or at both low and high GSM temperature extremes. Cultivars expressing these characteristics were defined in this study as low, high, or bipolar temperature sensitive, respectively. Cultivars unaffected by the range of the GSM temperatures experienced in the field in this study were classified as temperature insensitive on an individual quality characteristic basis.

Head color. GSM max temperature affected changes in head color more than min temperature for 'Citation', 'Baccus', and 'Packman' (Table 3). Of the three cultivars, head color of 'Citation' was most sensitive to GSM max temperature, followed next by 'Baccus' and then 'Packman', but 'Southern Comet' was influenced more by GSM min than max temperature.
Acceptability of 'Citation' head color decreased linearly with increasing GSM max temperature $\left(R^{2}=0.55\right)$, and this cultivar was considered high temperature sensitive relative to this characteristic. Ninety-five percent of all heads had acceptable color at $17.5^{\circ} \mathrm{C}$, which was the mean of the lowest GSM temperature experienced in this study (Fig. 1A). As GSM max temperature increased to 20.5 ${ }^{\circ} \mathrm{C}$, acceptability decreased below the $85 \%$ tolerance level, and head color rapidly degraded as max temperature increased. At 32.0 ${ }^{\circ} \mathrm{C},>55 \%$ of 'Citation' heads were off-color and unacceptable. 'Citation' does not have adequate heat tolerance, but performed better under cool rather than warm field conditions.

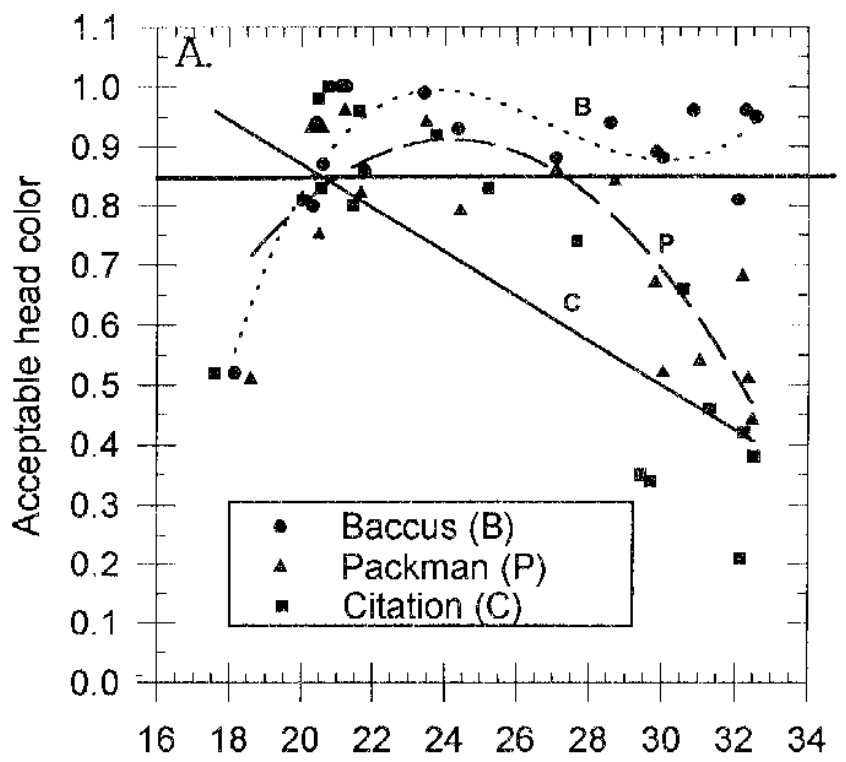

Growing season mean maximum temperature (C)

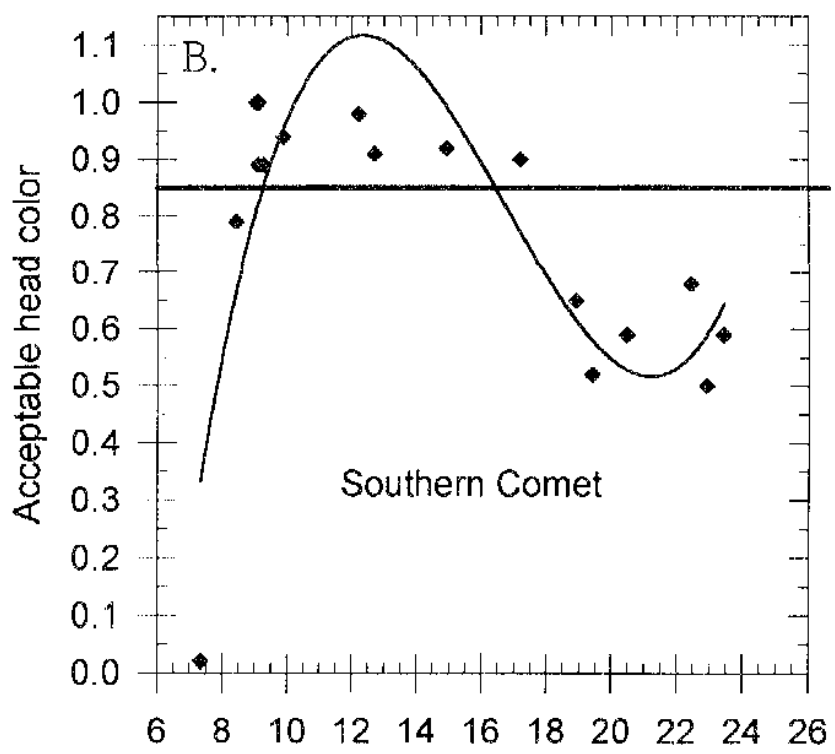

Growing season mean minimum temperature $(\mathrm{C})$

Fig. 1. (A) Influence of growing season mean maximum temperature on 'Baccus' (B), 'Citation' (C), and 'Packman' (P) head color quality. Thicker solid line indicates $85 \%$ tolerance level of acceptability. (B) Influence of growing season mean minimum temperature on 'Southern Comet' (SC) head color quality. Thicker solid line indicates $85 \%$ tolerance level of acceptability. 


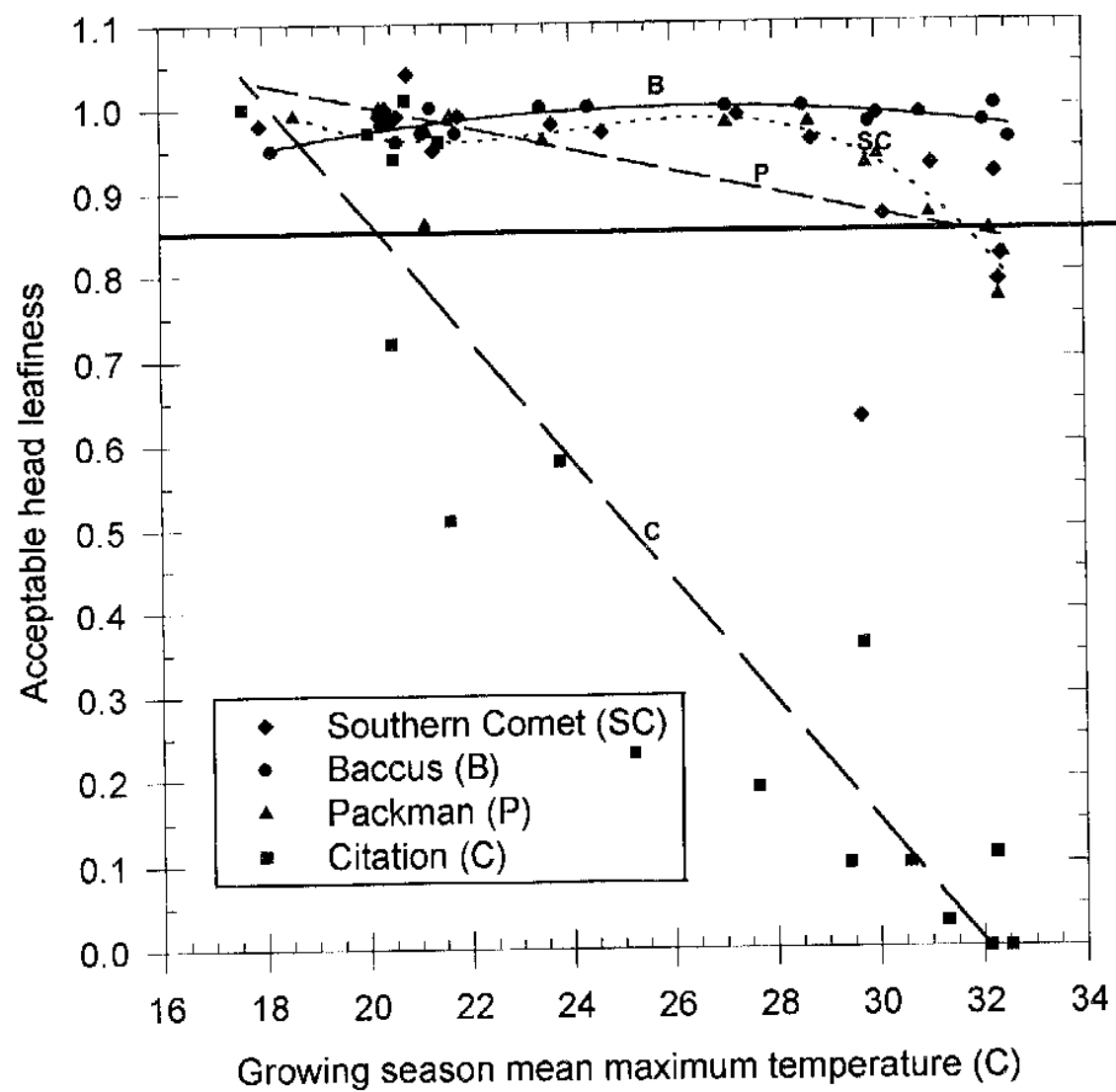

Fig. 2. Influence of growing season mean maximum temperature on head leafiness in 'Baccus' (B), 'Citation' (C), 'Packman' (P), and 'Southern Comet' (SC). Thicker solid line indicates $85 \%$ tolerance level of acceptability.

A third-order polynomial best described the effect of GSM max temperature on 'Baccus' head color $\left(R^{2}=0.72\right)$ (Table 3$)$, and this cultivar was considered low-temperature sensitive. At GSM temperatures below $20.3{ }^{\circ} \mathrm{C}$, head color was unacceptable (Fig. 1A). At $18{ }^{\circ} \mathrm{C}$, about $45 \%$ of all heads were off-color. As GSM temperatures increased from 18.0 to $20.3^{\circ} \mathrm{C}$, head color acceptability increased $30 \%$. At $23.5^{\circ} \mathrm{C}$, head color acceptability was optimal with $<5 \%$ of the heads experiencing off-color. As GSM max temperature increased to about $32^{\circ} \mathrm{C}$, the upper range of temperatures experienced in this study, head color remained acceptable. 'Baccus' cultivar expressed a strong level of heat tolerance relative to this characteristic, performing better under warmer than cooler field conditions.

A second-order polynomial best described the effect of GSM max temperature on 'Packman' head color $\left(R^{2}=0.65\right)$ (Table 3), and this cultivar was considered bipolar temperature sensitive. Head color was acceptable between 21.0 and $27.3^{\circ} \mathrm{C}$ and optimal at $24.5^{\circ} \mathrm{C}$, with $<8 \%$ of the heads exhibiting off-color (Fig. 1A). At $18{ }^{\circ} \mathrm{C}$, about $25 \%$ of all heads were off-color, which was $20 \%$ less than 'Baccus' at the same temperature. 'Packman' did better at lower GSM temperature than 'Baccus', but as temperature increased, 'Packman' head color quality rapidly decreased. At 32 ${ }^{\circ} \mathrm{C},>50 \%$ of 'Packman', but only $5 \%$ of 'Baccus', heads were offcolor.

GSM max temperature did not affect 'Southern Comet' head color, which was affected more by GSM min than max temperature (Table 3) and was considered a bipolar temperature sensitive cultivar. A third-order polynomial best described the effect of min temperature on 'Southern Comet' head color $\left(R^{2}=0.71\right)$. At $7.5^{\circ} \mathrm{C}$, about $35 \%$ of all heads had acceptable color, but, as temperature increased to $9.2{ }^{\circ} \mathrm{C}$, acceptability of head color increased to $85 \%$. Head color was acceptable between 9.2 and $16.5^{\circ} \mathrm{C}$, with optimal head color occurring at $12.5^{\circ} \mathrm{C}$ (Fig. 1B). Quality of head color decreased as temperature increased above $16.5^{\circ} \mathrm{C}$, with $48 \%$ of all heads off-color at 21.0 ${ }^{\circ} \mathrm{C}$.

Head leafiness. GSM max temperature affected head leafiness of all cultivars more than GSM min temperature (Table 3). 'Citation' was the most sensitive of all the cultivars to max temperature-induced head leafiness since its FSR $F$ value was highest, showing greater responsiveness than 'Baccus', 'Packman', and 'Southern Comet', which all had similar F values. $R^{2}$ values of the best equations from PR analysis ranged from 0.43 to 0.87 for these cultivars.

A second-order polynomial best described the effect of GSM max temperature on 'Baccus' head leafiness $\left(R^{2}=0.51\right)$, which was considered temperature insensitive to changes in head leafiness induced by max temperature. Head leafiness in 'Baccus' was stable within the complete range of GSM max temperatures experienced in this study, which ranged from 17.5 to $32.5^{\circ} \mathrm{C}$. At $32.5^{\circ} \mathrm{C}$, $<5 \%$ of the heads were unacceptably leafy (Fig. 2). Leafiness in broccoli heads is a typical physiological symptom of heat stress (Heather et al., 1992). Haine (1951) reported that bracts develop rapidly when the inflorescence is subjected to high temperature at the time of flowering. The ability of 'Baccus' to resist forming bracts within heads under high-temperature field conditions suggested a higher degree of heat tolerance than the other cultivars.

'Citation' was the most susceptible cultivar to high-temperature-induced leafiness and considered high-temperature sensitive. A linear equation best described the effect of GSM max temperature on 'Citation' head leafiness $\left(R^{2}=0.87\right)$ (Table 3$)$. Head leafiness was acceptable up to $20.2^{\circ} \mathrm{C}$ and as GSM max temperature increased, head leafiness increased (Fig. 2). At $25.0^{\circ} \mathrm{C}, 50 \%$ of 'Citation' heads were extremely leafy and, at $32.0^{\circ} \mathrm{C}, 100 \%$ of the heads were leafy and unacceptable. 'Citation' more accurately conformed to the usual heat stress induced bract formation as described by Haine (1951) and Heather et al. (1992).

A third-order polynomial equation best described the effect of GSM max temperature on 'Packman' head leafiness $\left(R^{2}=0.79\right)$ (Table 3) and was considered a high-temperature sensitive cultivar. Few 'Packman' heads were leafy at lower GSM temperatures and remained leafless until about $32.0^{\circ} \mathrm{C}$. As GSM temperatures increased above $32.0^{\circ} \mathrm{C},>15 \%$ of 'Packman' heads were moderately leafy. 'Packman' exhibited tolerance to bract formation similar to 'Baccus', yet, 'Baccus' produced $>95 \%$ acceptable heads at $32.0{ }^{\circ} \mathrm{C}$ versus $82 \%$ for 'Packman'.

A linear equation best described the effect of GSM max temperature on 'Southern Comet' head leafiness $\left(R^{2}=0.43\right)$ (Table $3)$ and was considered high-temperature sensitive similar to 'Citation' and 'Packman'. 'Southern Comet' head leafiness increased with GSM max temperature but remained within the acceptable range to $32.0^{\circ} \mathrm{C}$ (Fig. 2). In comparison, head leafiness in 'Southern Comet' was not as stable as 'Baccus' and 'Packman'.

Head density. Head density of 'Packman' and 'Southern Comet' were affected more by GSM min than max temperature (Table 3). A third-order polynomial equation best described the effect of 
GSM min temperature on 'Packman' head density, and this cultivar was considered bipolar temperature sensitive $\left(R^{2}=0.67\right)$. At $12.0^{\circ} \mathrm{C}$, head density was optimal, but below $8.0^{\circ} \mathrm{C}$ about $23 \%$ of the heads were loose (Fig. 3B). As GSM min temperature increased above $18.0^{\circ} \mathrm{C}$, looseness increased, with $25 \%$ of the heads considered unacceptable at $21.0{ }^{\circ} \mathrm{C}$, the maximal level of head looseness and unacceptability for this cultivar.

A third-order polynomial equation best described the effect of GSM min temperature on 'Southern Comet' head density, and this cultivar was bipolar sensitive temperature $\left(R^{2}=0.61\right)$ (Table 3$)$. Head density was unacceptable below $8.9^{\circ} \mathrm{C}$ with $>55 \%$ loose at $7.5^{\circ} \mathrm{C}$ (Fig. 3B). Head density was optimal at $12.0^{\circ} \mathrm{C}$, similar to

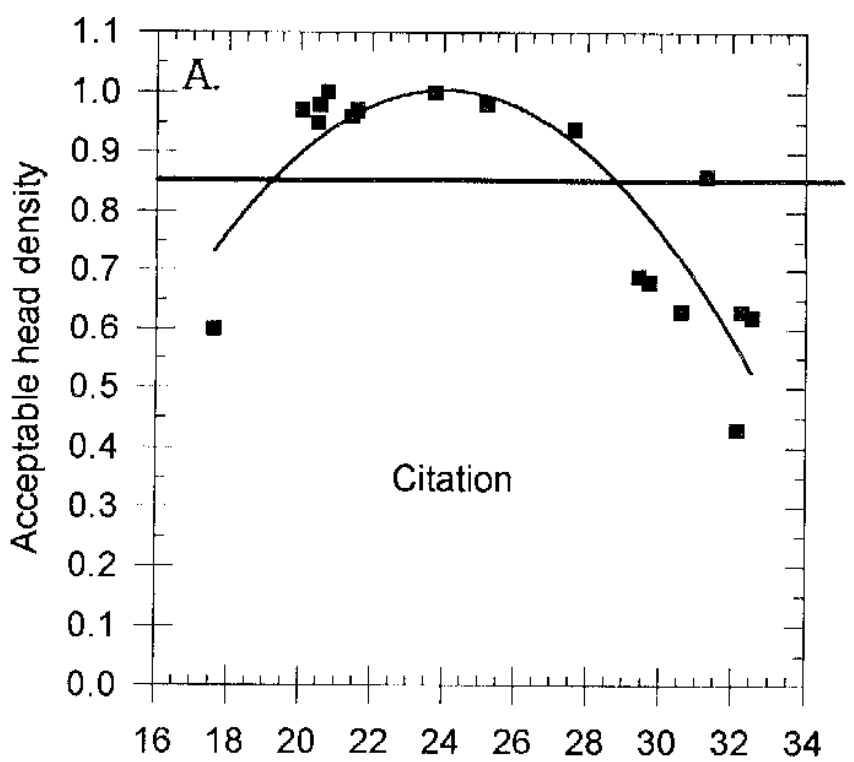

Growing season mean maximum temperature (C)

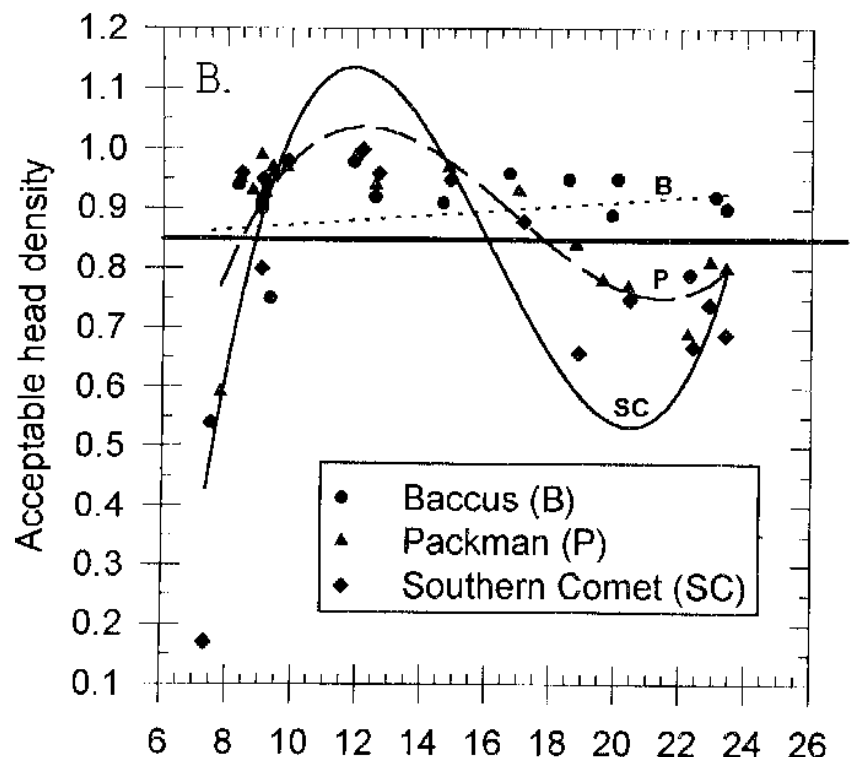

Growing season mean minimum temperature (C)

Fig. 3 (A) Influence of growing season maximum temperature on 'Citation' head density. Thicker solid line indicates $85 \%$ tolerance level of acceptability. (B) Influence of growing season minimum temperature on head density of 'Baccus' (B), 'Packman' (P) and 'Southern Comet' (SC). Thicker solid line indicates 85\% tolerance level of acceptability.
'Packman, but 'Southern Comet' was more sensitive to increasing GSM min temperature than 'Packman'. Head density remained acceptable to about $16.2^{\circ} \mathrm{C}$, but as GSM temperature increased to $21.0^{\circ} \mathrm{C}$, head looseness increased to about $45 \%$.

GSM max temperature affected 'Citation' head density more than GSM min temperatures, and this cultivar was considered bipolar temperature sensitive (Table 3 ). A second-order polynomial equation best described the effect of max temperature on 'Citation' head density $\left(R^{2}=0.75\right)$. Head density was unacceptable below $19.0^{\circ} \mathrm{C}$, with $>25 \%$ loose heads (Fig. 3A). With increasing GSM temperature, head density increased and was optimal at 24.0 ${ }^{\circ} \mathrm{C}$. As GSM temperature increased, head density decreased below the $85 \%$ tolerance level and, at $32.0^{\circ} \mathrm{C},>40 \%$ of the heads were loose.

'Baccus' head density remained compact and was not affected by GSM min or max temperatures experienced during field studies (ranging from 7.5 to $32.5^{\circ} \mathrm{C}$ ). Therefore, 'Baccus' is considered temperature insensitive in relation to this quality variable.

Head shape. GSM max temperature affected head shape of all cultivars more than min temperature (Table 3 ). The F test value from FSR analysis indicated that head shape of 'Packman' was the most sensitive to GSM max temperature followed by 'Baccus', then 'Southern Comet'. Head shape of 'Citation' was the least responsive to GSM max temperature. 'Baccus', Citation', and 'Southern Comet' were considered bipolar temperature sensitive cultivars in relation to this quality variable, with optimal production of dome-shaped heads at 22.0 to $24.0^{\circ} \mathrm{C}$.

Head shape of 'Packman' changed linearly with GSM max temperature (Table 3). 'Packman' did not have a lower temperature limit in this study, since head shape was acceptable and optimal at $17.5^{\circ} \mathrm{C}$, the lowest GSM max temperature recorded (Fig. 4). 'Packman' was considered high-temperature sensitive, with head shape remaining acceptable to $22.0{ }^{\circ} \mathrm{C}$. As GSM temperature increased, acceptability of head shape linearly decreased and, at $32.0{ }^{\circ} \mathrm{C},>60 \%$ of the heads were misshapen.

Second-order polynomial equations best described the effects of GSM max temperature on 'Baccus', Citation' and 'Southern Comet' head shape $\left(R^{2}=0.78,0.39\right.$, and 0.63 , respectively) (Table 3 ). 'Baccus' head shape was unacceptable below $19.8^{\circ} \mathrm{C}$, with $>30 \%$ misshapen at $18.0^{\circ} \mathrm{C}$ (Fig. 4). 'Baccus' head shape was acceptable to $26.8^{\circ} \mathrm{C}$, but as GSM temperature increased to 32.0 ${ }^{\circ} \mathrm{C}$, misshapen heads increased by $45 \%$. 'Citation' head shape was unacceptable below $18.4{ }^{\circ} \mathrm{C}$, but this cultivar was not as sensitive to lower GSM temperature as 'Baccus' and 'Southern Comet'. 'Citation' head shape remained acceptable to $25.7^{\circ} \mathrm{C}$ but, at 32.0 ${ }^{\circ} \mathrm{C},>40 \%$ were misshapen. 'Southern Comet' head shape was unacceptable below 21.0 and above $25.3^{\circ} \mathrm{C}$, but acceptable within those GSM temperatures. Head shape of 'Southern Comet' was affected more at either low or high temperatures than 'Baccus' and 'Citation' at 18.0 and $32.0^{\circ} \mathrm{C}$, with $>30 \%$ and $75 \%$ of 'Southern Comet' heads misshapen, respectively.

Bead size. FSR analysis showed that bead size of all cultivars was unaffected by GSM min or max temperatures. Although not significant at $P=0.05$, acceptability of bead size decreased with increasing GSM max temperatures (data not shown). Therefore, all these cultivars were classified as temperature insensitive, and this head characteristic is strongly stable and unaffected by GSM temperatures with the range of these experienced in the field.

\section{Conclusions}

This research has indicated that individual broccoli cultivars generally respond differently to GSM temperature in relation to 


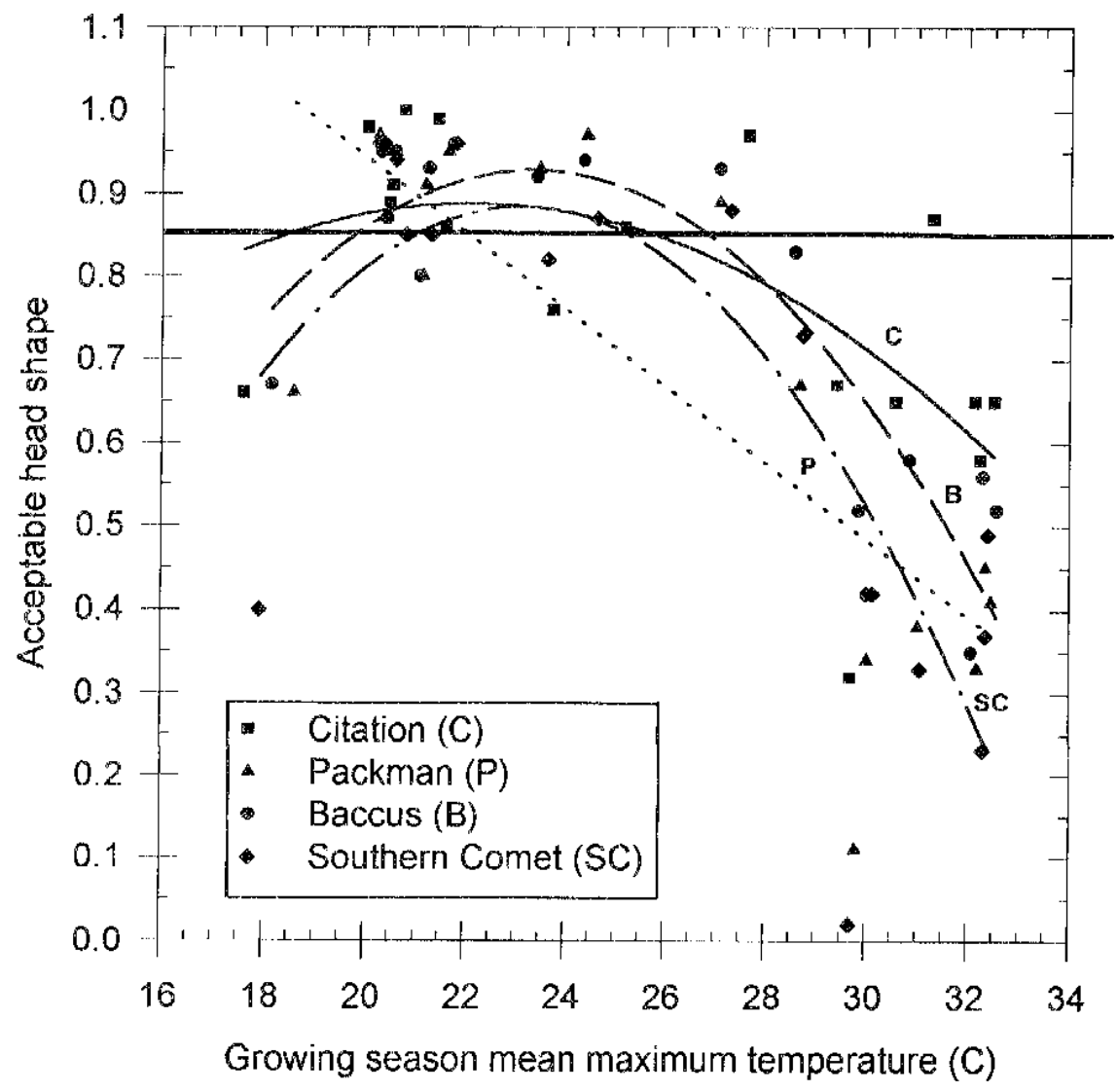

Fig. 4. Influence of growing season mean maximum temperature on head shape in 'Baccus' (B), 'Citation' (C), 'Packman' (P), and 'Southern Comet' (SC). Thicker solid line indicates $85 \%$ tolerance level of acceptability.

production of acceptable head quality (Table 4). For each cultivar, there are specific GSM temperature regimes (min, max, or both) that adversely affect the acceptability of head color, leafiness, density, and shape. GSM max temperature affected the expression of head leafiness and shape for all cultivars more than GSM min temperature. GSM max temperature also affected the expression of off-color in 'Baccus', 'Citation' and 'Packman' more than GSM min temperature, which was more effective in disturbing Southern Comet's head color. GSM min temperature affected head density in 'Packman' and 'Southern Comet' more than GSM max temperature, which was more effective in disturbing Citation's head density. Head leafiness and density of 'Baccus' was unaffected by the GSM min or max temperatures experienced in this study. Therefore, head quality, as defined in this study, in these cultivars appears to be strongly and uniquely influenced by the genome's interaction with GSM temperature. Pooling the response of these cultivars together would be inappropriate since novel response to temperature would be muted.

\section{Literature Cited}

Cook, W. 1990. Agricultural chemicals handbook. Clemson Univ. Coop. Ext. Serv. EC 670.

Fontes, M., J. Osbun, and S. Sadik. 1967. Influence of temperature on initiation of floral primordia in green sprouting broccoli. Proc. Amer. Soc. Hort. Sci. 91:315-320

Fujime, Y. 1988. A difference of response to low temperature between cauliflower and broccoli. Acta Hort. 218:141-151.

Gauss, J. and G. Taylor. 1969. Environmental factors influencing reproductive differential and the subsequent formation of the inflorescence of $\mathrm{Bras}$ sica oleracea L. var. Italica Plenck, cv. Coastal. J. Amer. Soc. Hort. Sci. 94:275-280.

Haine, K. 1951. Vegetative propagation from the broccoli curd after suppression of flowering. Nature 168:919.

Heather, D., J. Sieczka, M. Dickson, and D. Wolfe. 1992. Heat tolerance and holding ability in broccoli. J. Amer. Soc. Hort. Sci. 117:887-892.

Miller, C., T. Konsler, and W. Lamont. 1985. Cold stress influence on premature flowering of broccoli. HortScience 20:193195.

U.S. Department of Agriculture. 1977. United States standards for grades of bunched Italian sprouting broccoli. U.S. Dept. of Agr. Food Safety and Quality Serv., Washington, D.C.

U.S. Department of Agriculture. 1994. Vegetables and specialties: Outlook and situation. VGS-263.

Venturella, J., P. Rathwell, L. Bauer, and R. Caines. 1988. Potential market windows for selected vegetable crops in South Carolina. Clemson Univ. Expt. Sta. Bul. 663.

Wiebe, H. 1975. The morphological development of cauliflower and broccoli cultivars depending on temperature. Scientia Hort. 3:95-101.

Table 4. Growing season mean temperatures $\left({ }^{\circ} \mathrm{C}\right)^{\mathrm{z}}$ at which broccoli head quality is unacceptable at the range of temperatures experienced during 50 growing seasons at Charleston, S.C., from 1990 to 1992.

\begin{tabular}{|c|c|c|c|c|}
\hline Cultivar & Color & Leafiness & Density & Shape \\
\hline$\overline{\text { Baccus }}$ & $<20.3 \max$ & $---^{y}$ & --- & $<19.8$ and $>26.8 \max$ \\
\hline Citation & $>20.5 \max$ & $>20.2 \max$ & $<19.2$ and $>28.9 \max$ & $<18.4$ and $>25.7 \max$ \\
\hline Packman & $<21.0$ and $>27.3 \max$ & $>32.0 \max$ & $<8.4$ and $>18.0 \mathrm{~min}$ & $>22.0 \max$ \\
\hline Southern Comet & $<9.2$ and $>16.5 \mathrm{~min}$ & $>32.0 \max$ & $<8.9$ and $>16.2 \mathrm{~min}$ & $<21.0$ and $>25.3 \max$ \\
\hline
\end{tabular}

${ }^{\mathrm{z}}$ Temperatures derived from regression analysis. Mean minimum and maximum temperatures during the broccoli production seasons ranged from about 7.0 to $23.5^{\circ} \mathrm{C}$ and 18.5 to $32.5^{\circ} \mathrm{C}$, respectively.

${ }^{\mathrm{y}}$ Greater than $85 \%$ of all heads remained acceptable within the range of temperatures experienced in the field. 